
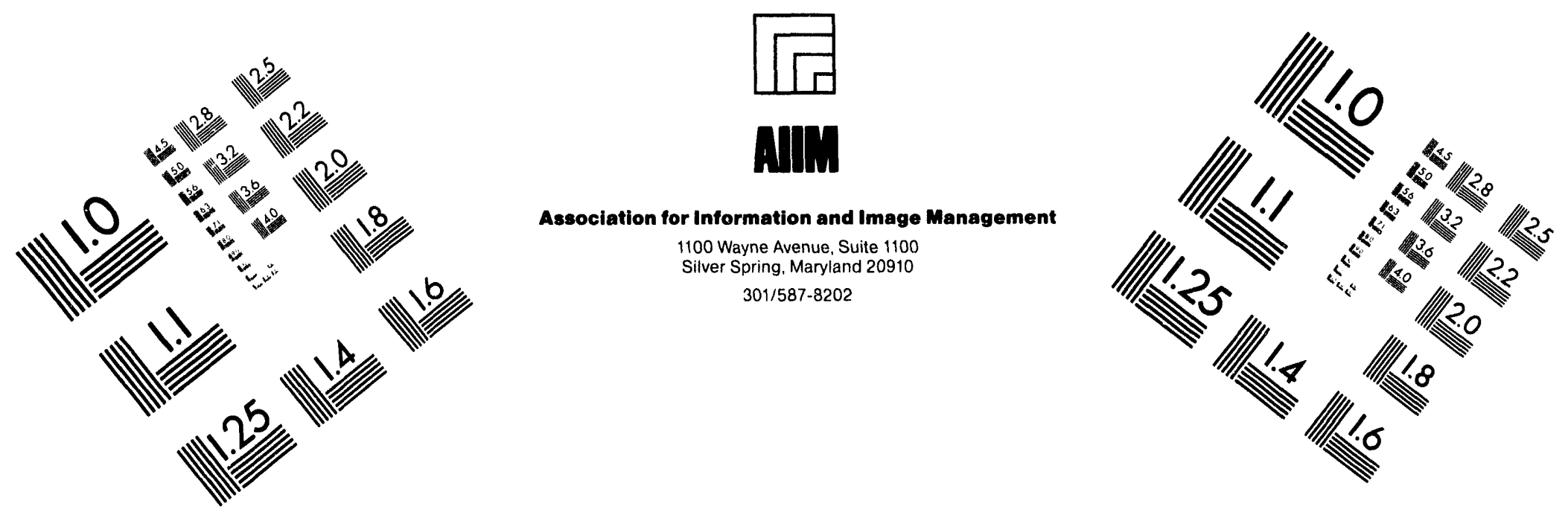

\title{
Centimeter
}

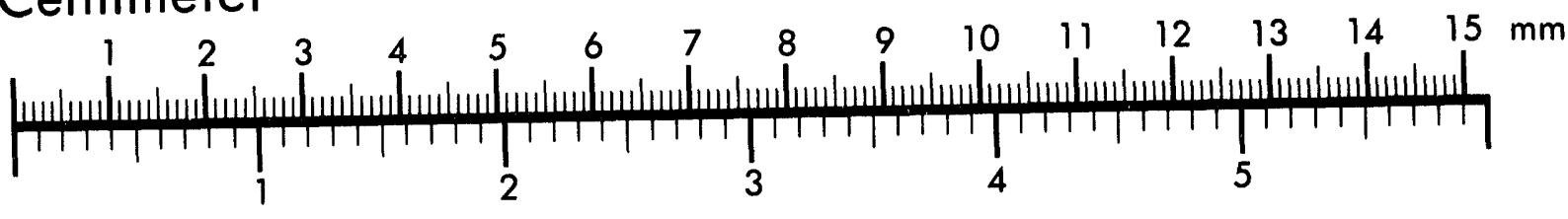
Inches
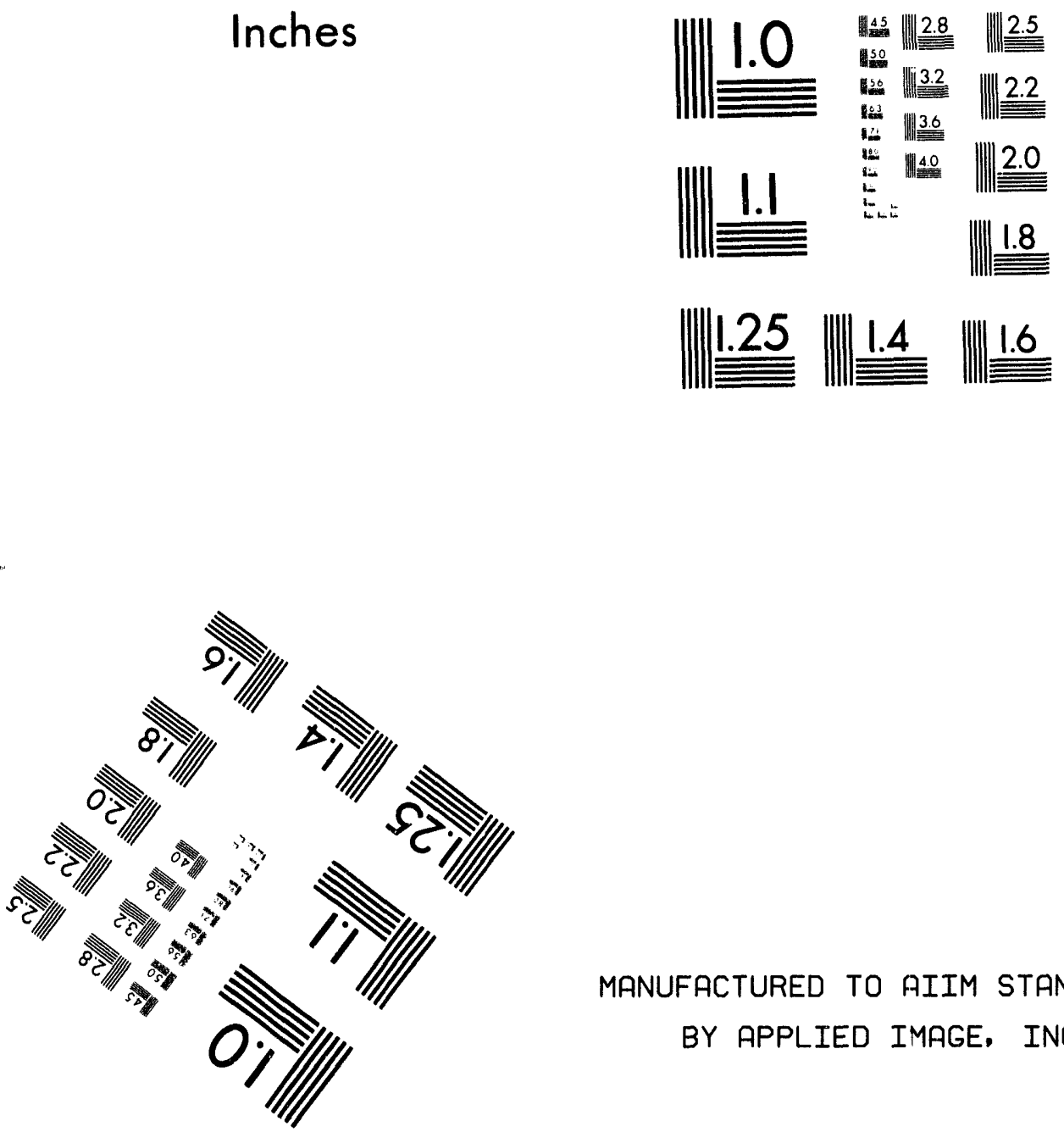

MANUFACTURED TO AIIM STANDARDS

$$
\text { BY APPLIED IMAGE, INC. }
$$

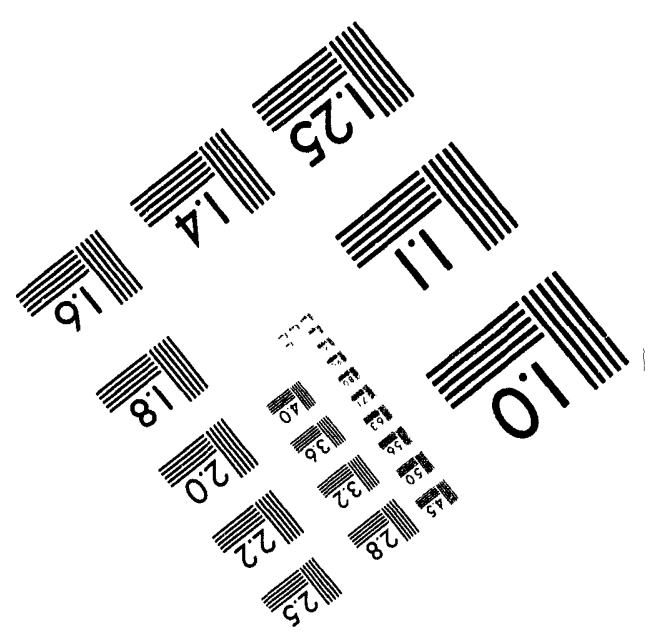



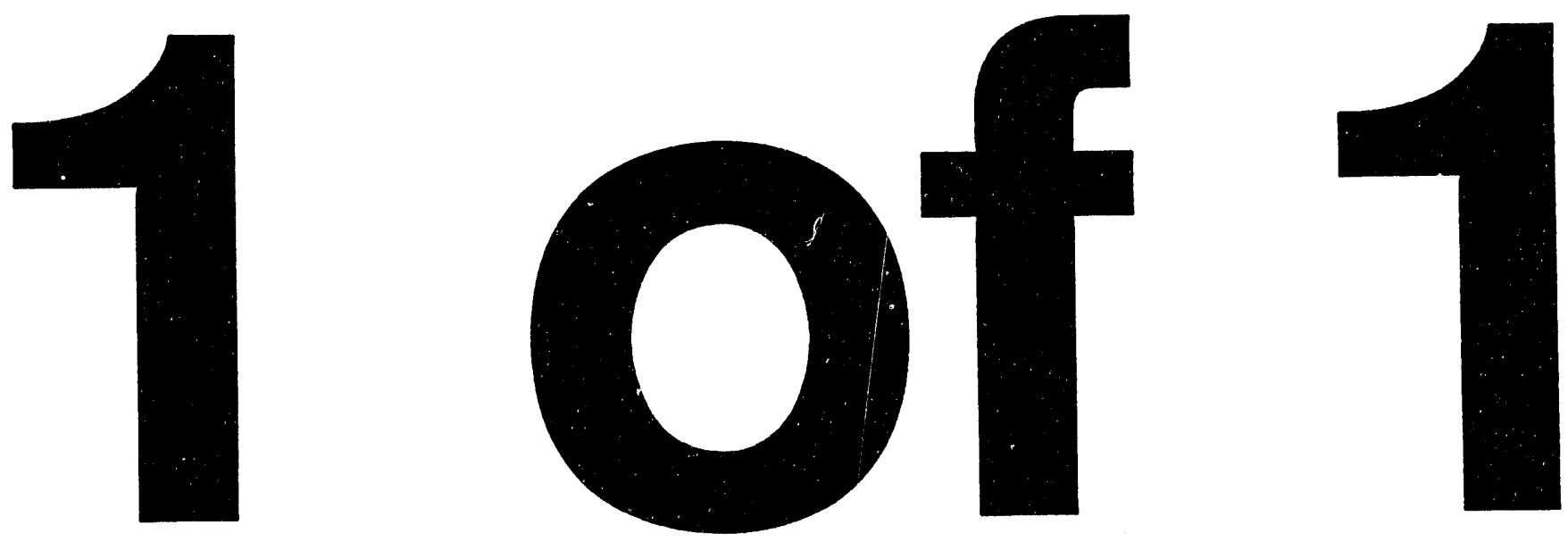


\section{Pacific Northwest Laboratory ALARA Report for Calendar Year 1993}

S. L. Keller

July 1994

Prepared for

the U.S. Department of Energy

under Contract DE-AC06-76RLO 1830

Pacific Northwest Laboratory

Richland, Washington 99352 


\section{SUMMARY}

This report provides summary results of the Calendar Year (CY) 1993 As Low As Reasonably Achievable (ALARA) Program at the Pacific Northwest Laboratory (PNL) ${ }^{1}$. This report includes information regarding whole-body exposures to radiation, and skin contaminations.

The collective whole-body radiation dose to employees during 1993 was 0.58 person-sievert ( 58 person-rem $)^{2}$. This dose was 11 percent lower than the projected dose of 0.65 person-sievert (65 person-rem). The Radiation Protection Section's Field Dosimetry Services group projected that no PNL employee's dose would exceed 0.02 sievert ( 2 rem) based on dosimeters processed during the year; no worker actually exceeded the limit by the end of CY 1993.

There were 15 reported cases of skin contamination for PNL employees during 1993. This number is 60 percent of the projected total of 25 cases. There were an additional 21 cases of personal-effects contamination to PNL staff: nine of these contamination events occurred at the 324 Building, nine occured at the 325 Building, one occured in the 327 Building, one occured in the 3720 Building, and one occured in the 326 Building.

Line management set numerous challenging and productive ALARA goals for their facilities. Appendix A describes the final status of the 1993 ALARA goals. Appendix B describes the radiological ALARA goals for 1994.

The Radiation Protection Section of the Laboratory Safety Department routinely perform audits of radiological ALARA requirements for specific facilities with significant potential for exposure. These ALARA audits are part of a comprehensive safety audit of the facility, designed to evaluate and improve total safety performance.

1 The Pacific Northwest Laboratory is operated by Battelle Memorial Institute for the U.S. Department of Energy under Contract DE-AC06-76RLO 1830.

2 The dosimetry records base the collective whole-body dose on dose to compliance-dosimeter-wearing PNL staff onsite only. All other data, discussions, conclusions, etc., in this report include both onsite and offsite information. 


\section{CONTENTS}

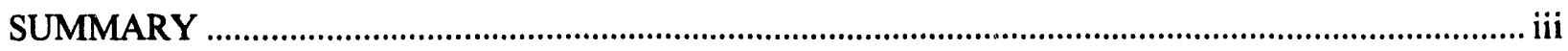

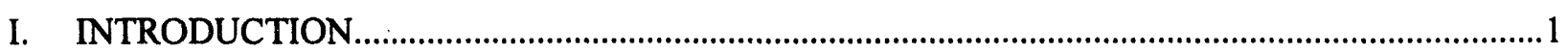

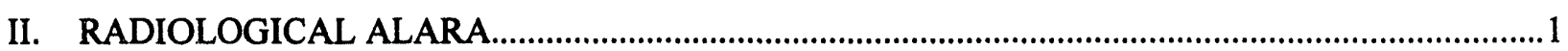

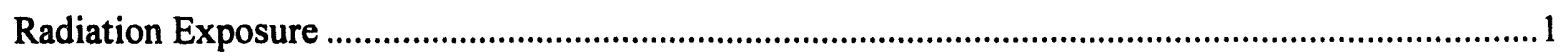

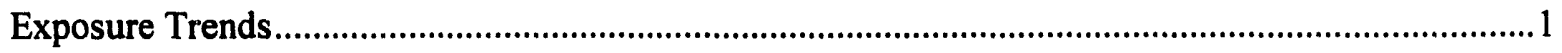

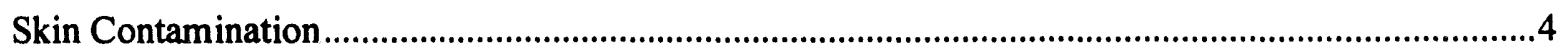

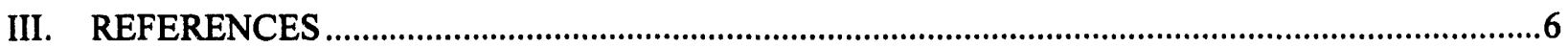

APPENDIX A - Status of Calendar Year 1993 ALARA Goals

APPENDIX B - Radiological ALARA Goals for Calendar Year 1994

APPENDIX C - Projections for Calendar Year 1994

APPENDIX D - Skin Contamination Cases During Calendar Year 1993

FIGURES

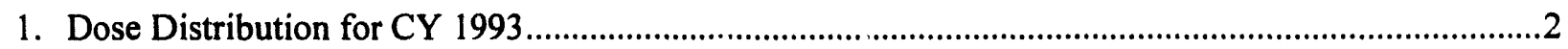

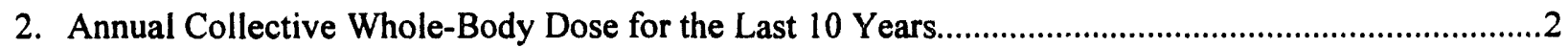

3. Collective Whole-Body Dose for 1990-1993 for the Five Highest Centers.........................................

4. Distribution of Dose Among High-Dose Departments, 1993 .........................................................

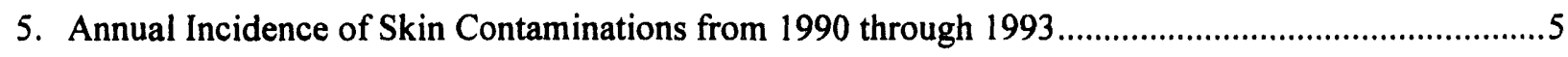

6. Annual Totals of Skin Contamination Cases by Year and Facility .................................................. 


\section{INTRODUCTION}

The concept of maintaining exposures to radiation as low as possible (ALAP) was first introduced formally in 1954 by the National Committee on Radiation Protection. DOE Order 5480.11, "Radiation Protection for Occupational Workers," establishes requirements for DOE contractor ALARA programs and references Health Physics Manual of Good Practices for Reducing Radiation Exposures to Levels that are As Low As Reasonably Achievable (ALARA), which describes possible elements of ALARA programs.

ALARA is a factor considered in all PNL projects. Chapter 1 of the DOE, Radiological Control Manual, provides guidance on PNL's radiological ALARA program. PNL trains all radiation workers in ALARA ideas and techniques. The purpose of this report is to summarize and document activities, accomplishments, and results of safety parameters involved in the ALARA Program during CY 1993.

The Radiological ALARA Program is administered by the PNL ALARA Coordinator of the Radiation Protection Section. The research and operational organizations develop ALARA goals; the ALARA Coordinator reviews these goals and tracks their progress throughout the year. The ALARA report displays CY 1993 radiological goals and their status in Appendix A; the CY 1994 radiological goals are in Appendix B. Line management implements the ALARA programs and Laboratory Safety and other organizations provide training and support.

\section{RADIOLOGICAL ALARA}

This section summarizes performance of the radiological ALARA Program at PNL. It includes information on radiation doses and skin contaminations and identifies the organizations with the highest doses.

\section{Radiation Exposure}

In CY 1993 staff members at PNL facilities on the Hanford Site who were monitored for compliance with DOE Order 5480.11 (i.e., multipurpose dosimeter wearers) received a total of 0.58 person-sievert (58 person-rem). At the beginning of the year, the ALARA Coordinator projected 0.65 person-sievert ( 65 person-rem), based on planned activities, primarily those in the 324 and 325 Buildings. The difference between projected and actual dose was 11 percent.

\section{Exposure Trends}

The ALARA Coordinator analyzed the distribution of doses among staff. Figure 1 shows the distribution of doses among the 1832 staff members who were monitored for compliance with DOE Order 5480.11. The average dose for this group during 1993 was 0.32 millisievert ( 32 millirem), compared to 0.34 millisievert ( 34 millirem) in 1992. The most frequently occurring dose for staff members during 1993 was 0 millisievert (0 millirem). 


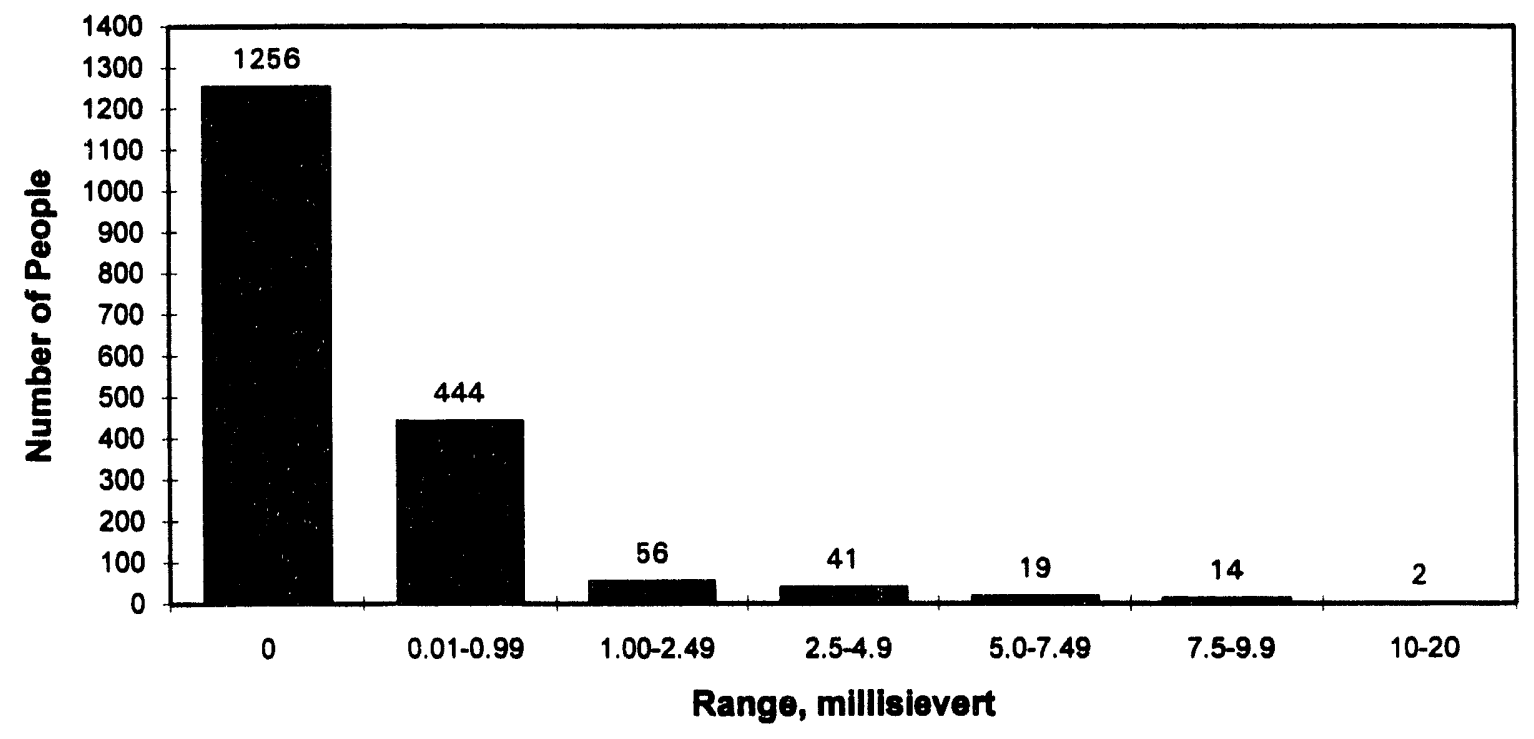

FIGURE 1. Dose Distribution for CY 1993

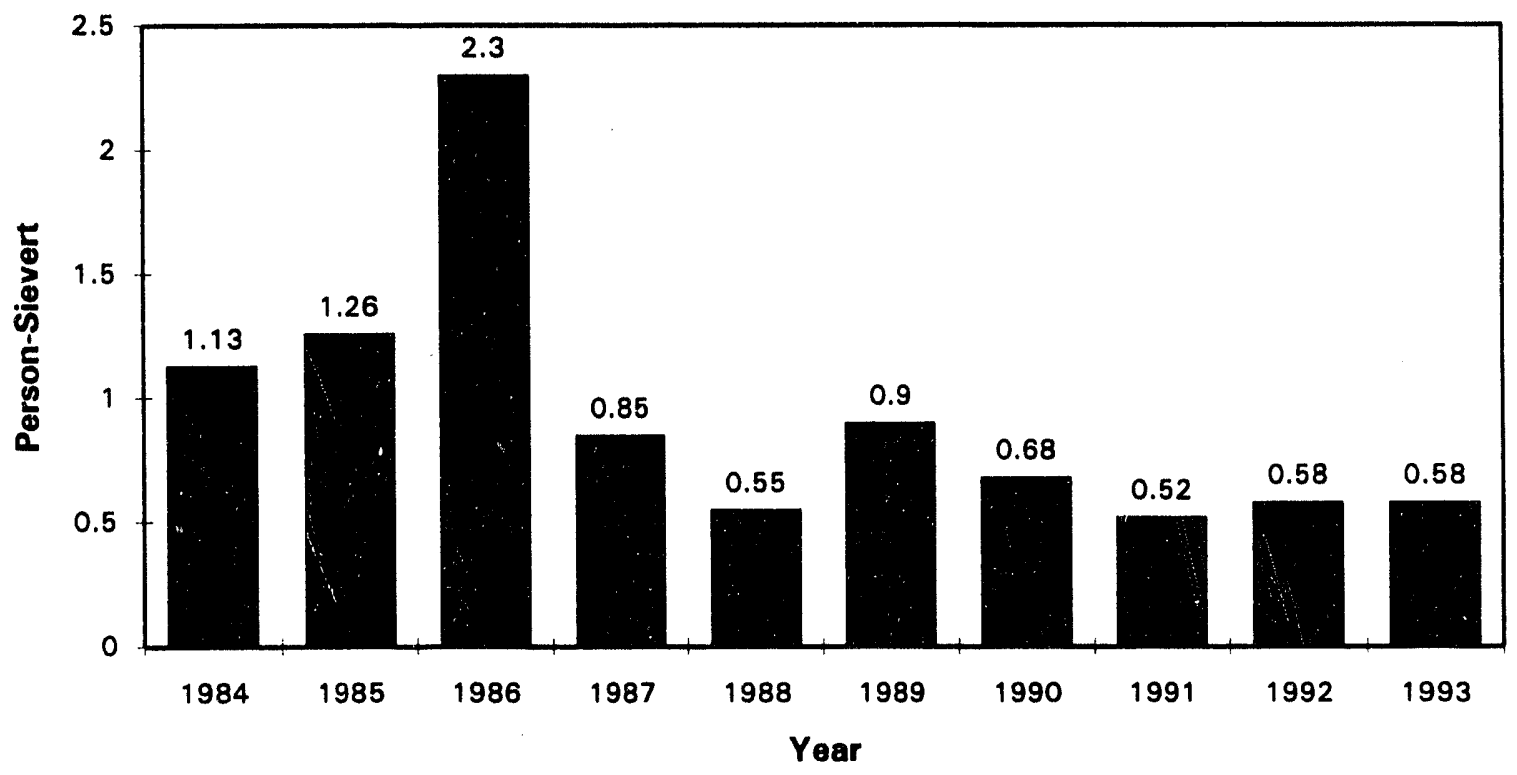

FIGURE 2. Annual Collective Whole-Body Dose for the Last 10. Years

Figure 2 shows the yearly trend in collective whole-body dose for PNL. The figure illustrates the correlation of collective dose to the major programs. The ALARA Coordinator relates the dose maximum in 1986 to the destructive examination phase of the steam generator project. The rise in collective dose in 1989 and 1990 was the result of the single-shell tank waste characterization. The 
majority of the collective dose in 1991 through 1993 is attributed to the 325 Building A Annex clean-out, and clean-out activities in the 324 Building B hot cell. The ALARA Coordinator expects the collective dose for PNL to remain below 1 person-sievert (100 person-rem) over the next several years, unless significant program changes occur.

Figure 3 shows the yearly trend in total collective whole-body dose incurred by the five centers or directorates with the highest collective whole-body doses for the last three years. The Facilities and Operations Directorate accounted for approximately 38 percent, the Waste Technology Center accounted for 31 percent, and the Materials and Chemical Sciences accounted for 20 percent of the total CY 1993 PNL collective whole-body dose.

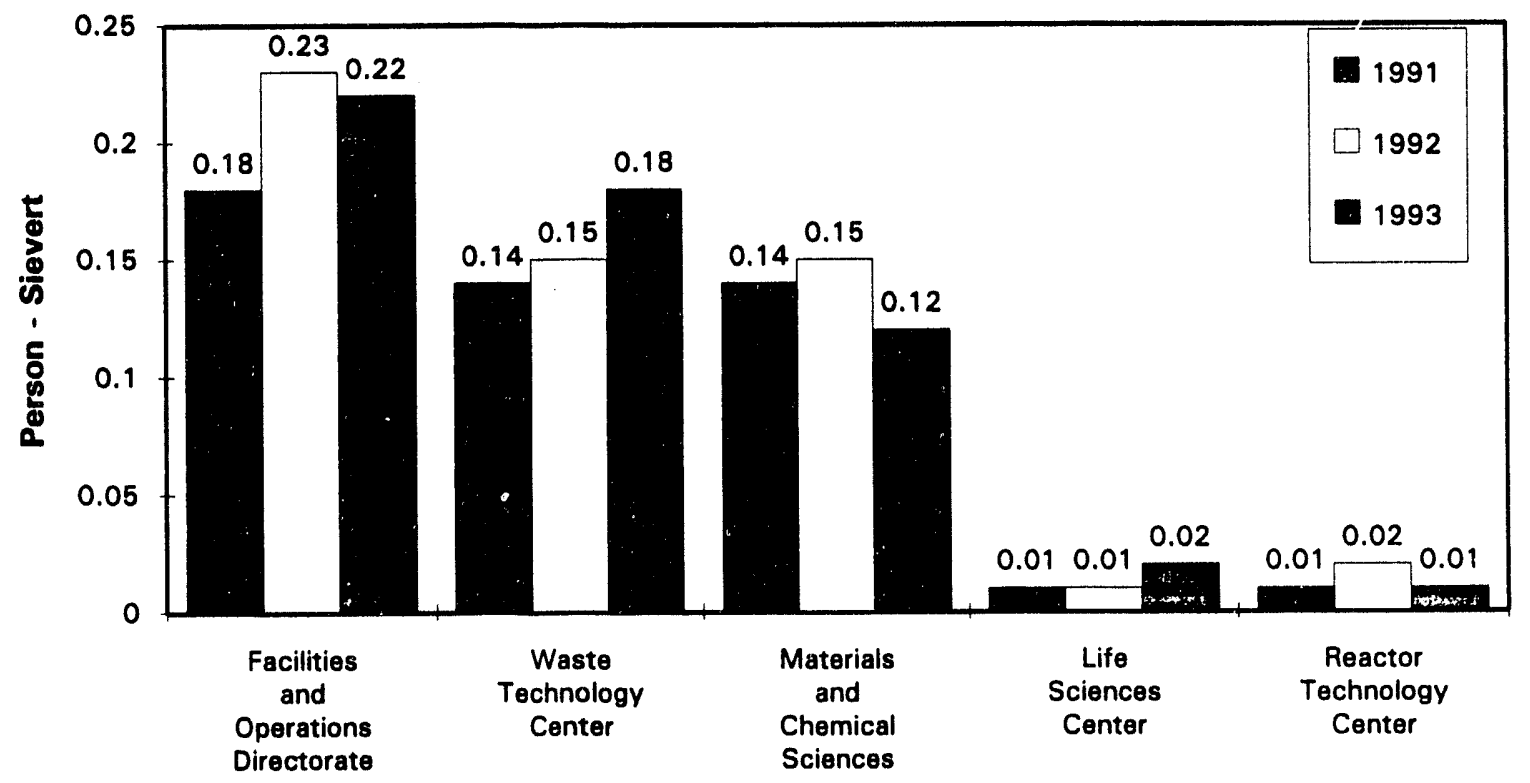

FIGURE 3. Collective Whole-Body Dose for 1990-1993 for the Five Highest Centers

Figure 4 shows the distribution of dose among PNL high dose organizations for 1993. The department incurring the highest collective dose was the Process Technology Department of the Waste Technology Center, which operates the majority of PNL's hot cell facilities, incurring 28 percent of the PNL collective dose. The Technical Services Department, Facilities and Operations Directorate received 17 percent of the PNL total. This dose results from support of the research and facility operations and maintenance. The Laboratory Safety Department, also of the Facilities and Operations Directorate, received approximately 17 percent of the PNL collective dose, the majority of which is due to routine activities of the Radiation Protection Technologists in support of the hot cell clean-out activities in the 324 and 325 Buildings. The Chemical Technology Department of the Materials and Chemical Sciences Center received 9 percent of the total. The Chemical Sciences Department of the Materials and Chemical Sciences Center received 6 percent of the total. The Materials Sciences Department had 5 percent of the total. The ALARA Coordinator attributes the majority of the dose for all of these departments to staff who work in the 324, 325 and 327 Buildings.

Observing the centers' and departments' trends of collective dose totals over the years indicates that the level of the collective dose relates directly to the number of projects involving work with radioactive 
materials. A qualitative analysis of the 1993 overall collective dose totals for PNL has shown typical or expected values when compared with the recent years' totals (after 1986). The actual dose for 1993 was 11 percent lower than projected.

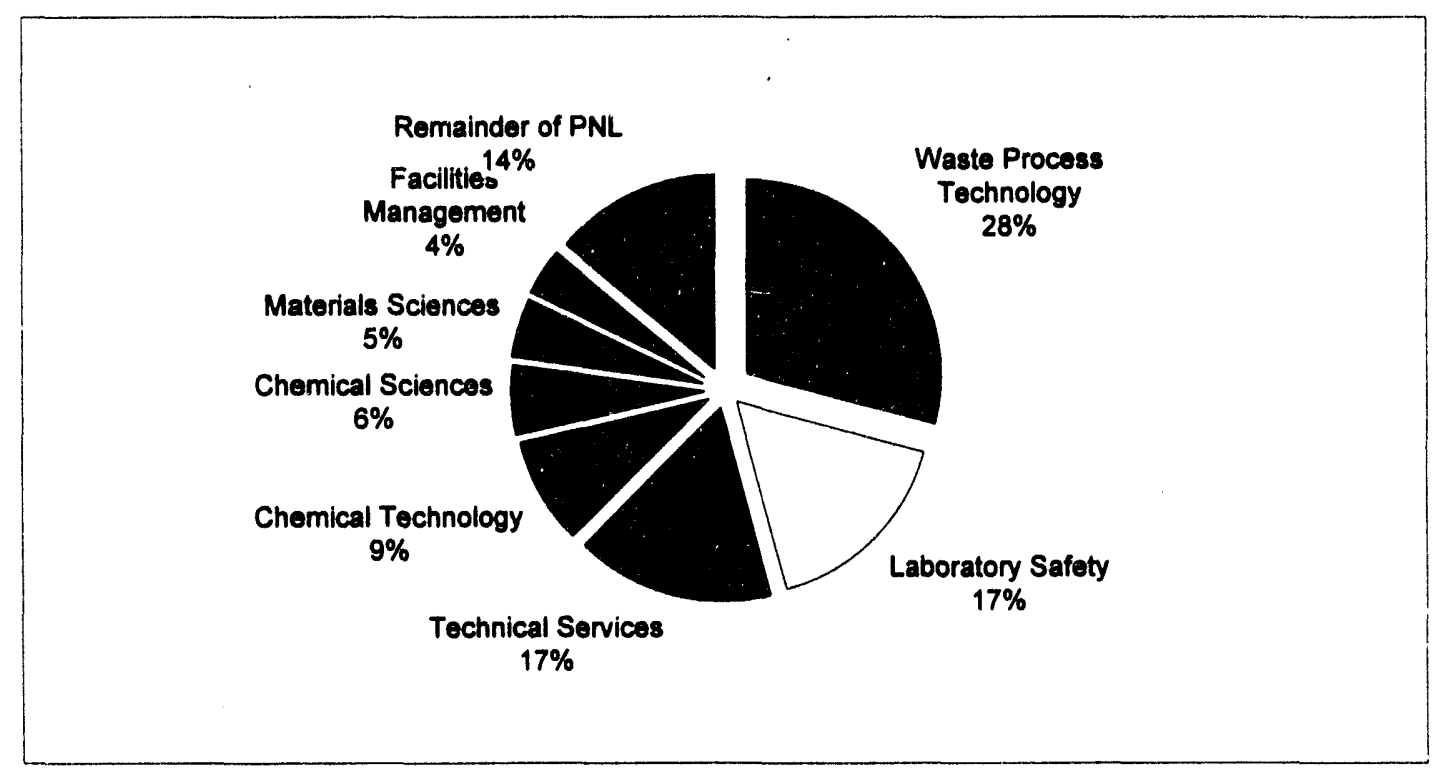

FIGURE 4. Distribution of Dose Among High-Dose Departments, 1993

\section{Skin Contamination}

In CY 1993, PNL staff had a total of 15 cases of skin contamination compared to an estimated number of 25 (Appendix D). Figure 5 shows the historical trend of yearly skin contaminations for the period 1990 to 1993 . The stabilization of the number of skin contaminations is mostly due to heightened staff awareness, attention to detail while removing protective clothing, and a decrease of the use of personal clothing in contaminated and potentially contaminated areas.

An analysis of the available data indicates that the rate of the skin contaminations, as well as number of the skin contaminations, remained essentially constant in 1993 as compared to 1992 . The number of entries into Radiologically Controlled Areas in all years is approximately 500,000.

Figure 6 provides a breakdown of skin-contamination cases by facility since 1990 . Nine of the 1993 cases occurred in the 324 Building, and six occured in the 325 Building. At the beginning of the year, the ALARA Coordinator projected 25 cases based on planned activities and historical trends. 


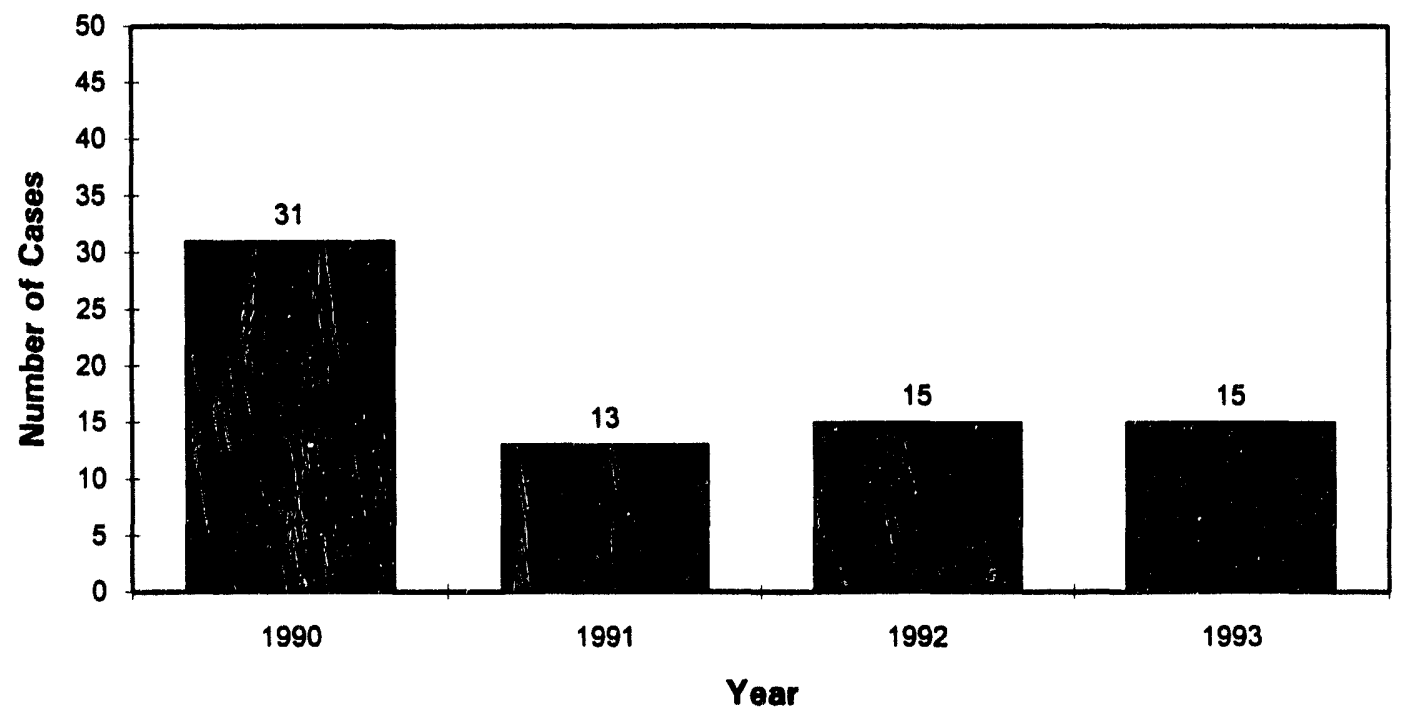

FIGURE 5. Annual Incidence of Skin Contaminations from 1990 through 1993

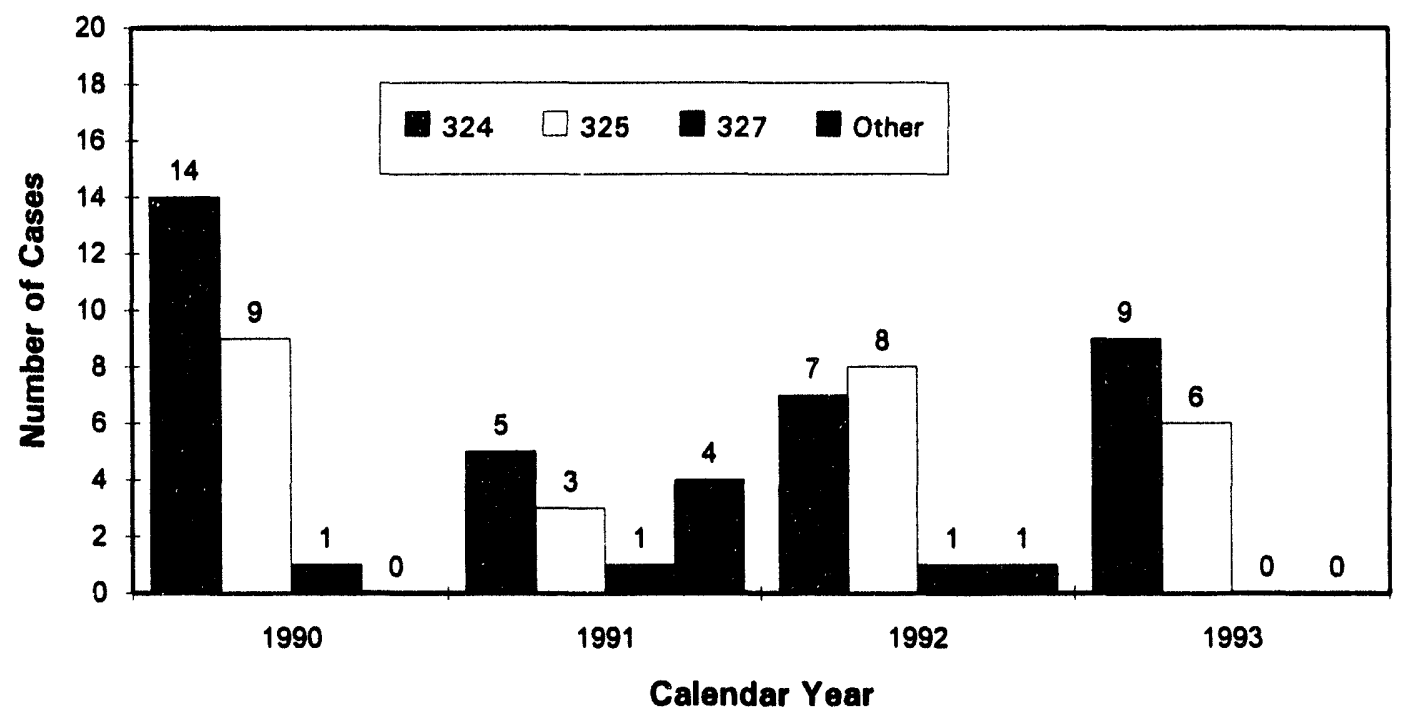

FIGURE 6. Annual Totals of Skin Contamination Cases by Year and Facility 


\section{REFERENCES}

U.S. Department of Energy (DOE). 1992. "Radiation Protection for Occupational Workers." DOE Order 5480.11.

U.S. Department of Energy (DOE). 1988. "Health Physics Manual of Good Practices for Reducing Radiation Exposure to Levels that are As Low As Reasonably Achievable (ALARA)." PNL-6577, Pacific Northwest Laboratory, Richland, Washington.

U.S. Department of Energy (DOE). 1990. "Radiological Control Manual." DOE N 5480.6. Washington, D.C. 


\section{APPENDIX A \\ STATUS OF CALENDAR YEAR 1993 ALARA GOALS}

The following organizations had A'_ARA goals for CY 1993: Waste Technology Center (WTC), Reactor Technology Center (RTC), Materials and Chemical Sciences Center (MCSC), and the Laboratory Safety Department (LS).

The majority of the CY 1993 /LARA goals were completed. Three goals were not completea due to circumstances beyond the control of the organization; two of these were put on hold and one was carried forward to 1994.

This appendix examines the goals individually, stating the goal number and a statement of the goal. The statement of the goal will be followed by a summary of final progress. The goals are numbered according to the organization working on the goal, the building where the work is being done, and a sequential number.

Goal Number

306W-93-1

306W-93-2

306W-93-3

$325-93-1$

$325-93-2$

$325-93-3$

$324-93-1$

$324-93-2$

$324-93-3$
Goal Status

Reduce inventory of Uranium; reduce background radiation level.

Reduce amount of liquid radioactive waste in room 132; reduce unnecessary personnel dose.

Reduce probability of contamination from cracked flooring by replacing flooring.

Remove and dispose of Pu-contaminated glovebox; reduce dose rate and contamination hazard in room 410.

Remove contamination hot spots from 325 Building A Annex floor; reduce dose hazard.

Design and fabricate shielded waste-handling system for Shielded Analytical Facility; reduce personnel dose.

Design and install new track system for removal of waste from the 324 Building main hot cell airlock. Use of new track systcin will reduce time in the airlock and industrial hazards.

Design and fabricate remote decontamination viewing system for reduction of dose and contamination.

Reduce volume of waste from analytical instrumentation.
Completed.

Completed.

This goal was put on hold.

Completed.

This goal was put on hold.

Completed.

This goal was carried forward to 1994.

Completed.

Completed. 
$327-93-1$

$327-93-2$

$327-93-3$
Identify and dispose of waste from 327 Building B and G-hot cells.

Reduce personnel dose in 327 Building canyon room by removing painted-over contamination, etc.

Reduce the use of the hazardous solvent

1,1,1-trichlorethane with non-hazardous substitute.
Completed.

Completed.

Completed. 


\section{APPENDIX B}

\section{RADIOLOGICAL ALARA GOALS FOR CALENDAR YEAR 1994}

The Material and Chen.ical Sciences Center (MCSC) and Engineering Technology Center (ETC) have radiological ALARA goals. The ETC is a combination of last year's Reactor Technology Center (RTC) and the Waste Technology Center (WTC).

Goal Number

MCSC-306W-94-1

MCSC-306W-94-2

MCSC-325-94-1

MCSC-325-94-2

ETC-324-94-1

ETC-324-94-2

ETC-324-94-3

ETC-324-94-4

\section{Synopsic of God}

Improve contamination detection capabilities upon exiting from the depleted-uranium processing and machining areas through the installation of the intermediate personalsurvey and clothing-change area at or near this work location. This goal will reduce the area of contamination by 100 square feet and reduce the machining-operations personnel contamination incidents.

Return $10,000 \mathrm{~kg}$ of depleted uranium to an Army sponsor. This action will allow the 306-W Building to become a non-nuclear facility and will reduce radiation readings in the building. This action will also reduce the radiation reading on the north wall from $4 \mathrm{mR} / \mathrm{h}$ to $2 \mathrm{mR} / \mathrm{h}$.

Review analytical chemistry laboratory $(\mathrm{ACL})$ radioactive sample-storage locations to eliminate samples that are no longer required and to cor solidate the number of storage areas in ACL space. This goal is expected to reduce radioactive-storage locations by one-third and collective dose by 10 percent.

Remove and replace high efficiency particulate air (HEPA) filter on glovebox 38-A, Room 604 . This goal will reduce the whole-body dose received by personnel working at the glovebox.

High-dose-rate waste containers will be shielded using concrete barrier blocks. The containers will be stored in a portion of the waste-storage enclosure that was constructed in FY 1993. This goal is expected to reduce staff collective dose by approximately $60 \mathrm{mrem} / \mathrm{y}$.

A waste compactor will be installed in the radiochemical engineering cell airlock. Current plans are to compact all airlock wastes, such as those generated from cask handling or decontamination operations, into 30-gallon drums. These drums will then be removed from the airlock into 55-gallon shielded drums. This goal is expected to reduce the collective dose to waste handlers approximately $1 \mathrm{rem} / \mathrm{y}$.

A new track and dollie system will be designed and fabricated to replace the current system. This goal will result in a collective exposure reduction for Hot Cell Operations staff approximately $1.2 \mathrm{rem} / \mathrm{y}$.

Modify the pendant control on the 30/5-ton overhead bridge crane from a fixed position to a non-fixed (festooned) type. This goal will reduce collective PNL exposures by approximately $250 \mathrm{mrem} / \mathrm{y}$. 
ETC-324-94-5

ETC-327-94-1

ETC-327-94-2
Fabricate and install new step plugs to replace existing contaminated plugs. This goal is expected to reduce contamination incidents to the gallery from an average of 1.5 times per year to 0 times per year.

Reduce the easily dispersible contamination and radiation readings at transfer and equipment ports at $\mathrm{F}$ cell. Achievement of this goal will be assessed by performing radiation readings at the transfer and equipment ports before material transfers $(>5 \mathrm{R} / \mathrm{h})$. The expected reduction is from the present $>5 \mathrm{R} / \mathrm{h}$ to $<1 \mathrm{R} / \mathrm{h}$.

Reduce the radiation-dose-rate readings on the top of I cell by evaluating and moving the spent fuel stored in the cell and removing that which is not currently needed to support the on-going spent-fuel study. The expected reduction during transfers through the port is from the present $>2 \mathrm{R} / \mathrm{h}$ to $<200 \mathrm{mr} / \mathrm{h}$. 


\section{APPENDIX C \\ PROJECTIONS FOR CALENDAR YEAR 1994}

The projections for CY 1994 are based on several sources. The primary source is the individual organization's estimate of collective dose based on planned activities. The ALARA Coordinator reviews these estimates and makes an independent appraisal of high-dose organizations, then combines the estimates into a PNL-wide collective dose estimate. Other sources taken into account are historical and recent trends in dose and contamination, as well as the year-to-date collective doses and contamination events. This estimate is relatively accurate because exposure rates for certain tasks is relatively well known, and extensive planning occurs before a new task is undertaken. An increase/decrease in exposure is expected for 1994 as the pace of hot cell clean-out activities increases, as well as several repairs to hot cell facilities.

The estimate for the expected number of skin contaminations is based on planned work in contamination areas, past trends, planned training, and expected effectiveness of protective clothing. This projection is subject to wide variations from year to year due to the relatively small number of events that occur and to unexpected sources of contamination. As the majority of the high-dose jobs are planned to occur in very high-contamination areas, the ALARA Coordinator projected the same number of skin contaminations as projected for 1993, despite the low number of actual skin contaminations.

Very few new or unexpected uptakes of radioactive materials have occurred at PNL in recent years; therefore, none are projected. The uptakes in past years have been either chronic uranium uptakes in the millirem range or offsite uptakes of tritium. No new uptakes are projected for CY 1994.

\section{The Projections for CY 1994 are as follows:}

0.65 person-Sievert (65 person-rem) collective whole-body dose.

25 skin contaminations. 


\section{APPENDIX D \\ SKIN CONTAMINATION CASES IN CALENDAR YEAR 1993}

There were 15 cases of skin contamination of PNL staff at the Hanford Site in 1993, 60\% of the projected 25 cases. Of these 15 cases, nine were in the 324 Building, six in the 325 building. The table below lists the skin contaminations in chronological order, the building where the contamination occurred, a brief description of the details of the event, a listed cause of the occurence type, and occurence date.

An occurrence classifier determined the severity and the cause of the evınt according to the guidance given by DOE Order 5000.3B. The occurrence classifiers determined that all skin contaminations in CY 1993 fit the category of "Off-Normal Occurrence." The Off-Normal Occurrence reports describe all skin contaminations in more detail and can be found in the Occurrence Reporting and Processing System (ORPS) database using the occurrence number listed below. Note: All occurrence numbers have the prefix RL-PNL.

In addition to the 15 skin-contamination events, there were 21 events involving personal-effects contamination.

\section{$\begin{array}{llll}\text { NUMBER } & \text { BLDG } & \text { DETALS } & \text { TYPE DATE }\end{array}$}

324-1993-0002 $324 \quad$ Personnel contamination after work in fume hood in room

ONO $\quad 1 / 8 / 93$

147. Staff member was wearing protective clothing and it is believed the protective clothing was contaminated before he put it on.

324-1993-0003

Personnel contamination during removal of rack in B cell.

ONO

$1 / 29 / 93$

Entry into the cubicle, earlier the same day, allowed undetected spread of contamination.

324-1993-0004

Personnel contamination of right sole of shoe after work in

ONO the REC airlock event which was due to a rapid removal of protective clothing after an individual was escorted from the airlock with heat-prostration symptoms. 

exit from the REC airlock. Source believed to be from condensate dripping from the doorframe at the exit of the airlock.

324-1993-0007

324-1993-0008

324-1993-0010

324-1993-0011

324-1993-0013

324-1993-0014

324-1993-0016

324-1993-0018

324-1993-0020

324-1993-0024

324-1993-0025

324-1993-0026

Personnel head and hair contamination. Event due to careless ONO removal of protective respirator.

KEH personnel hair contamination. Event due to

ONO

Personnel shoe contamination, after working in B-cell airlock. ONO Source was unknown. Staff member was wearing proper protective clothing (bubble suit).

Personnel skin contamination, after support work to staff in a ONO radiologically controlled area. Source is believed to have transferred from protective clothing to personal clothing.

Personnel clothing contamination after working in B-cell ONO gallery. Two subsequent contamination events are included in the 10-day report. Source believed to be protective clothing from the laundry.

An RPT was found to have radioactive contamination on the little finger of his right hand. The cause was from handling electronic dosimeters before entering of the radiological area.

KEH shoe contamination after load test of 6-ton crane in 324 ONO

B-cell airlock. Contamination occurred during careless undress.

Personnel clothing was contaminated. Staff member became ONO contaminated when he came in contact with contaminated protective clothing from laundry.

Personnel skin was contaminated. Staff member perspired in ONO a protective suit, which broke the tape seal around the neck area and allowed contamination to enter.

Shoe was contaminated. Staff member became contaminated ONO after washing down the hot-cell airlock. Protective clothing and shoe covers worn. The source was unknown.

Skin contamination of wrist. Staff member became contaminated after installing conduit in the B-cell gallery. Source believed to have transferred from glove to wrist during careless undress.

Skin contamination was detected after a technician's exit from ONO the hot-cell airluck. There was an RWP violation, in that only one pair of gloves was worn. 
325-1993-0001

325-1993-0002

325-1993-0003

325-1993-0004

325-1993-0005

325-1993-0006

325-1993-0007

325-1993-0010

325-1993-0011

325-1993-0012

325-1993-0013

325-1993-0015

325

325-1993-0016
Personnel contamination of right chest area, after working in ONO room 400 . The source was unknown.

325 Personnel contamination of shoe after work in room 511. The ONO source was unknown.

325 Personnel contamination of right hand after counting a sample ONO in room 425. Contamination was due to loose contamination that fell off a contaminated counting plate.

Personnel contamination of heel of right shoe after

ONO maintenance work on evening shift. Source believed to be transferred from the static mat at the PCM to staff member's shoe.

Personnel contamination of right pant leg after exit survey. Source believed to be from contaminated labcoat.

Personnel contamination of right palm after exit survey.

ONO

Source was traced to a pipette in room 313.

Personnel contamination of face, lip, and hair after

ONO

$3 / 3 / 93$

decontamination solution splashed in her face.

Radioactive contamination found on right shoe of KEH

ONO

$3 / 31 / 93$ construction worker. The source was unknown.

$4 / 7 / 93$

Radioactive contamination found on right hand of technician. ONO Contamination acquired during analytical work, after using inadequate pipette. No gloves were worn.

Radioactive contamination found on hands of $\mathrm{KEH}$

ONO

$5 / 3 / 93$ construction worker, after work in room 302. Event caused by inadequate fixative coating over previous contamination in ductwork in the floor.

Radioactive contamination found on PNL staff member's shoe ONO after working in a surface contamination area. Contamination was transferred from contaminated protective shoe covers.

Contamination of KEH staff member's shoe during ONO $5 / 17 / 93$ construction work. Alpha particle was deeply imbedded on shoe and believed to have been present before entering the work area.
A technician was found to have a contaminated forefinger upon exit from room 400 , which is a radiation area. The source is $\mathrm{Sr}-\mathrm{Y}$, which came from contaminated cabinetry used for laboratory equipment. 

work. The source was unknown; the staff member was not working with radioactive samples and did not use a fume hood.

A staff member was found to have a contaminated sole of right shoe after exit from the 325 Building A Annex area. The source was unknown.

PNLBOPEM-1993- 327 0003

The RLWS alarm sounded at the low-point arain line. Water ONO was leaking from a previously sealed isolation valve. Shoes of two staff member's became contaminated in the investigation of the leak $(100 \mathrm{mr} / \mathrm{hr})$.

PNLBOPER-1993.

Personal clothing contamination (non-PF iz employee) after work in normal research and development activities. Contamination may be due to unbuttoned laboratory coat during work.

PNLBOPER-1993 - 3720

Research and development technician found contamination on ONO 0036 shoe sole. He had not been in any areas requiring shoe covers. Source was unknown and had decayed to nondetectable levels by the next day. 


\section{Distribution}

No. of

Copies

Offsite

2 DOE/Office of Scientific and Technical Information

\section{Onsite}

2 DOE Richland Operations Office

D. L. Clark

A5-55

6 Westinghouse Hanford Company

J. F. Dickman (5)

D. A. Hammond
No. of

Copies

$44 \quad$ Pacific Northwest Laboratory

W. I. Apley

P7 -46

V. C. Asmund

P7-78

T. C. Chikalla

M. F. Gillis

M. J. Graham

P7-75

K1 $1-50$

$\mathrm{K} 6-78$

K7-02

P7-78

D. P. Higby

G. R. Hoenes

S. L. Keller (15)

E. L. Kelley

L. V. Kimmel

R. R. King

D. E. Knowlton

W. W. Laity

M. A. Lowe

L. H. Munson

B. D. Robertson

B. D. Shipp

M. A. Showalter

J. W. Wald

R. A. Walters

W. R. Wiley

M. A. Williams

G. L. Work

Publishing Courdination

Technical Report Files (5)
P7.78

P7-78

K6-78

P7-70

P7-70

P7-40

K2-50

P7-18

K3-56

K8-28

K8-28

P7-18

K2-22

K1-50

R3-77

P7-60

K7-02

K1-06 

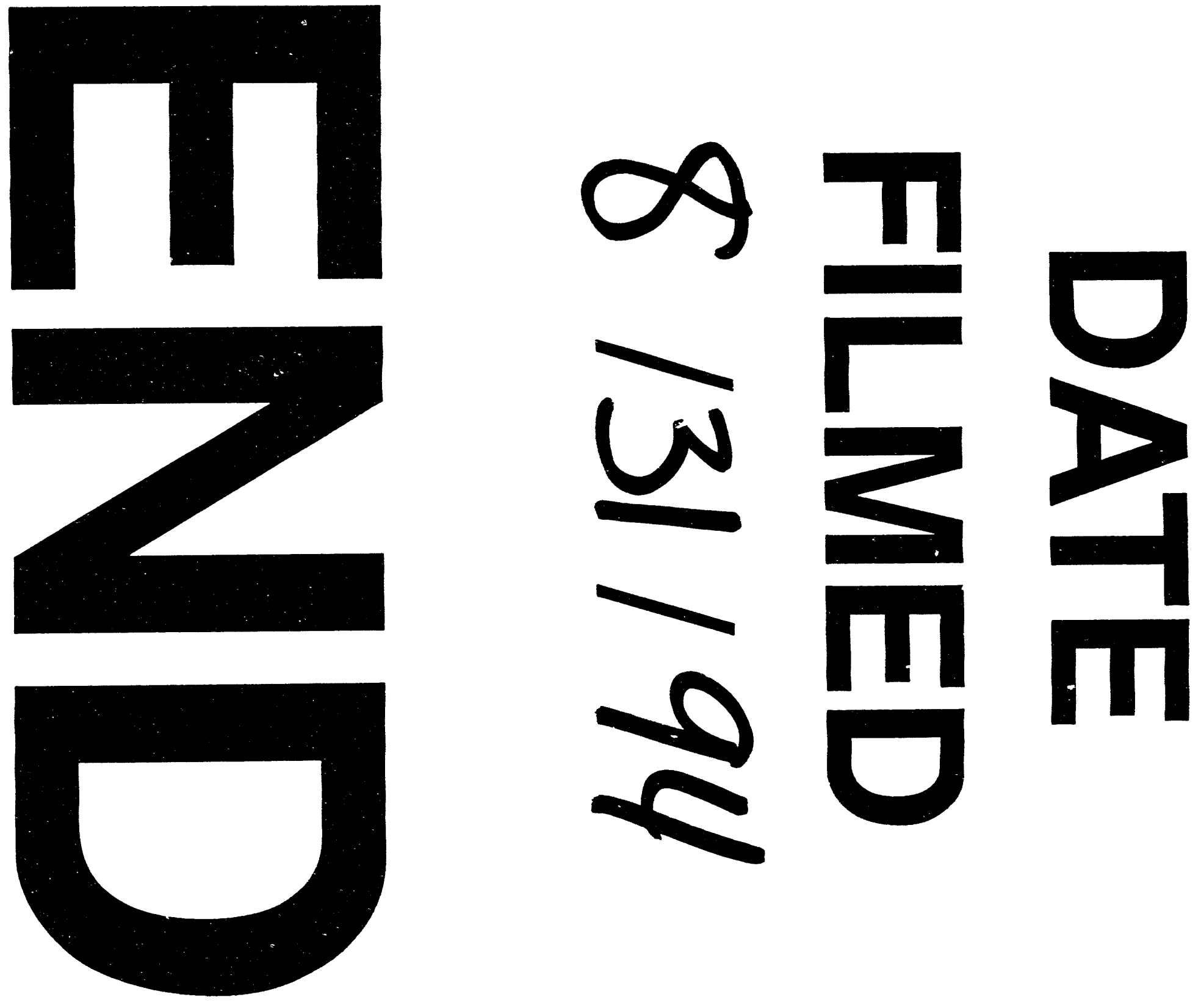
